reason to suspect an Indian origin for the blood factor shown to be present in the father's blood and also present in the affected infant's coated red blood cells.

These findings indicate that a factor of extremely low incidence in a general population may have a much higher incidence in other population groups. To a lesser degree this applies also to other blood factors, such as the well-established differences in incidence of type $R h_{0}$ in caucasoids and African negroes. The point at issue here is the usefulness of the term 'low incidence' to characterize certain blood factors. 'Low incidence' is preferable to 'family' or 'private', and the term is still helpful because it characterizes the first observations made with a particular blood factor.

Most significant is the occurrence of a high incidence of matings incompatible for a particular blood factor capable of causing hæmolytic disease in a population which is almost exclusively $R h$ positive ${ }^{4}$. It can be safely predicted that, in the Caribe Indians or in any population with a high incidence of incompatible matings for $D i^{a}$, this factor may play a part in causing hæmolytic disease comparable in importance to the $D\left(R h_{o}\right)$ factor in caucasoids provided that the two factors have the same degree of antigenicity.

If the genetically related $D i^{b}$ and anti- $D i^{b}$ exist, the antibody should be sought among the homozygotes of genotype DiaDia of the Caribe Indians.
PhinIP Levine

E. A. RoBINSON

Division of

Immunohematology,

Ortho Research

Foundation,

Raritan, New Jersey.
Miguel Layrisse

Tulio Arends

R. Domingues Sisco

Centro de

Investigaciones,

Banco Municipal de Sangue,

Caracas, Venezuela.
${ }^{1}$ Levine, P., Koch, E., McGee, R., and Hill, G., Amer. J. Clin. Path. 24, 292 (1954)

2 Levine, P., Fifth International Congress of Blood Transfusion, Reports and Communications, Paris (1954).

${ }^{3}$ Hart. M. vander, Bosman, H., and Van Loghem, J., Vox Sang., 4, 108 (1954).

- Layrisse, M., Arends, T., and Sisco, R. D., Acta Medica Venez., 3, 132 (1955).

- Fernandes et al., personal communication from Dr. P. C. Junqueira, Rio de Janeiro, Brazil.

\section{The Diego Blood Factor in Brazilian Indians}

IT has been pointed out that what appears to be a rare, private or family antigen in one population may be fairly frequent in another. For example, the antigen which had sensitized an Amerindian woman so that she lost the child of her ninth pregnancy through erythroblastosis was found in the blood of her husband and of some of her children, but not in the blood of 794 other Amerindians, and it was therefore considered to be rare. However, when tested with the blood of Caucasians, the antibody could be shown just to be anti-Kell, the Kell factor being quite frequent in the Caucasian sample.

An analogous situation also involving Amerindians and Caucasians is provided by the Diego factor recently described by Levine, Koch, MeGee and Hill $^{2}$. This factor, discovered to be the cause of an erythroblastosis case in a Venezuelan family, was first considered to be rare because two hundred whites tested in the United States were all negative. However, Layrisse, Arends and $\mathrm{Sisco}^{3}$, testing
266 people from Caracas and 61 from Barcelona (Venezuela), found $6(2 \cdot 3$ per cent) and $2(3 \cdot 3$ per cent), respectively, to be Diego-positive, and they ascribed this finding to Indian admixture. Testing two groups of Caribe Indians-121 in Cachama and 49 in Santa Clara of Aribi-they found 43 (35.6 per cent) Diego-positives in the first group and $7(14 \cdot 3$ per cent) in the second. In addition, $8(5 \cdot 3$ per cent) Diego-positives were found among 152 Guajires Indians belonging to the Arawco group.

We had the opportunity of testing two groups of Brazilian Indians with the anti-Diego serum using the anti-globulin method. The first group of 48 Kaingángues, living in a reservation near Palmas, State of Parana, included 22 (46 per cent) which gave a positive reaction. The second group consisted of 36 Carajás living at Santa Isabel, Bananal Island, among whom 13 Diego-positives ( 36 per cent) were found. Both groups of Indians belong to the linguistic family of the $\mathrm{Ge}$ and live some 1,100 miles apart.

If the Diego factor, as at present seems possible, is universally common among Amerindians and absent or mostly absent among whites, it might provide some indication of the degree of Amerindian admixture in many American populations. Studies of its infiltration and of the resulting antigenic incompatibility might also be rewarding.

Thanks are due to Dr. M. Layrisse for a gift of anti-Diego serum and to Dr. J. Dausset for its transport.

\section{P. C. JUNQUeIra \\ P. J. WISHART}

Secao Investigacao Cientifica,

Banco Sangue P.D.F., Rio de Janeiro.

\section{F. OtTensooser \\ R. PAsqualin}

Laboratorio Paulista Biologia, São Paulo.

\section{P. Lourei:io Fernandez}

Department of Anthropology,

University of Parana, Curitiba.

\section{H. KaLMUS}

Galton Laboratory, University College, London. Nov. 6.

${ }^{2}$ Chown, B., and Lewis, M., Nature, 171, 700 (1953). 2 Levine, P., Koch, E. A., McGee, R. T., and Hill, G. H., Amer.
J. Clin. Path., 24, 292 (1954).

${ }_{3}$ Layrisse, M., Arends, T., and Sisco, R. D., Acta Med. Venez., 3, 132 (1955).

\section{Absence of Abnormal Hæmoglobins in some Australian Aboriginals}

WHEN the sickle cell trait was found to be present in a number of Veddoid communities of southern India ${ }^{1}$, it was also found that their rhesus chromosome distribution showed features differing from those of other Indian populations, and that it was more like those found in South-East Asia, Australasia, and especially in the Australian aboriginals. We therefore examined seventy-two Australian aboriginals for the presence of the sickle cell trait, but found that none of them showed this abnormality ${ }^{2}$. Since then, other abnormal hæmoglobins besides the sickle cell hæmo- 